\title{
Rescue Vaginal Cerclage to Stop Funneling Following Laparoscopic Cerclage
}

\author{
Tayfun Cok $^{1 \odot}$ \\ ${ }^{1}$ Department of Obstetrics and Gynecology, School of Medicine, \\ Baskent University, Adana, Turkey
}

Rev Bras Ginecol Obstet 2021;43(10):794-795.

\section{Dear Editor,}

Laparoscopic cerclage is an effective treatment option for cervical insufficiency leading to repeated preterm birth. However, surgical intervention with various cerclage techniques, such as vaginal, transabdominal laparoscopic approaches, still remains the ultimate solution, unfortunately, without the guarantee of success. ${ }^{1-3}$ There is still no consensus regarding the priority of each technique over the other. However, when laparoscopic cerclage fails to completely treat cervical insufficiency, an additional vaginal cerclage should be considered as a rescue intervention. We suggest considering Shirodkar vaginal cerclage a rescue technique following laparoscopic transabdominal cerclage which is compromised by further funneling. Here, we report, after obtaining written consent, the cases of three patients who needed additional vaginal cerclage to prevent further funneling and membranous bulging despite intact laparoscopic cerclage material.

These three patients had recurrent pregnancy loss despite having undergone vaginal cerclages. Demographic data, as well and the obstetric and surgical histories of the patients, are shown in - Table 1. Considering their history, the first preferred intervention was laparoscopic cerclage. However, we detected funneling and bulging of amniotic membranes below the level of the laparoscopic cerclage during their follow-up visits. Then, we performed an additional Shirodkar vaginal cerclage to prevent further funneling. The images of the patients' cervix immediately after the Shirodkar cerclage are shown in -Fig. 1. The patients were followed-up with frequent ultrasound (US) examinations; images of funneling following vaginal cerclage persisted in two patients, whereas funneling disappeared completely in one patient after vaginal cerclage. All patients had uneventful deliveries at 38 weeks.

received

August 30, 2021

accepted

September 18, 2021
Address for correspondence Tayfun Cok, MD, 79. Sokak 7/6 Bahçelievler 06490, Ankara, Turkey (e-mail: tayfuncok@yahoo.com).

Table 1 Demographic data, and obstetric and surgical histories of the patients

\begin{tabular}{|c|c|c|c|}
\hline Patient & 1 & 2 & 3 \\
\hline Age & 36 & 33 & 34 \\
\hline Gravida & 10 & 5 & 3 \\
\hline Para & 1 & 1 & 0 \\
\hline Abortus & 8 & 3 & 2 \\
\hline $\begin{array}{l}\text { Previous gynecological } \\
\text { operation }\end{array}$ & $\begin{array}{l}\text { Septum } \\
\text { resection }\end{array}$ & None & None \\
\hline Live birth & 1 at 28 weeks & 1 at 30 weeks & None \\
\hline $\begin{array}{l}\text { Number of previous } \\
\text { elective McDonald } \\
\text { vaginal cerclages }\end{array}$ & 3 & 2 & 1 \\
\hline L/S cerclage & + & + & + \\
\hline Issue & Funneling & Funneling & Funneling \\
\hline $\begin{array}{l}\text { Week at performance } \\
\text { of vaginal } \\
\text { Shirodhar cerclage }\end{array}$ & $\begin{array}{l}13 \text { weeks, } \\
5 \text { days }\end{array}$ & $\begin{array}{l}23 \text { weeks, } \\
2 \text { days }\end{array}$ & $\begin{array}{l}26 \text { weeks, } \\
1 \text { day }\end{array}$ \\
\hline Delivery at & $\begin{array}{l}38 \text { weeks, } \\
3 \text { days }\end{array}$ & $\begin{array}{l}38 \text { weeks, } \\
1 \text { day }\end{array}$ & $\begin{array}{l}38 \text { weeks, } \\
2 \text { days }\end{array}$ \\
\hline
\end{tabular}

Laparoscopic abdominal cerclage is an effective management option for refractory cervical insufficiency. It is reported to improve the rates of second-trimester loss and neonatal survival, ${ }^{4}$ and to be superior to low vaginal cerclage, especially for patients with failed previous vaginal cerclage. ${ }^{5}$ However, it can be insufficient in conditions such as laparoscopic interventions with loose first knots or medial deviation into the cervical stroma during suturation, or vaginal infections. Further funneling and bulging of amniotic membranes can be warning signs of pregnancy loss even after an uneventful and intact laparoscopic cerclage. This condition can be due to congenital or acquired cervical tissue defects, previous repeated surgeries of the cervix, or a lax

(C) 2021. Federação Brasileira de Ginecologia e Obstetrícia. All rights reserved.

This is an open access article published by Thieme under the terms of the Creative Commons Attribution License, permitting unrestricted use, distribution, and reproduction so long as the original work is properly cited. (https://creativecommons.org/licenses/by/4.0/)

Thieme Revinter Publicações Ltda., Rua do Matoso 170, Rio de Janeiro, RJ, CEP 20270-135, Brazil 

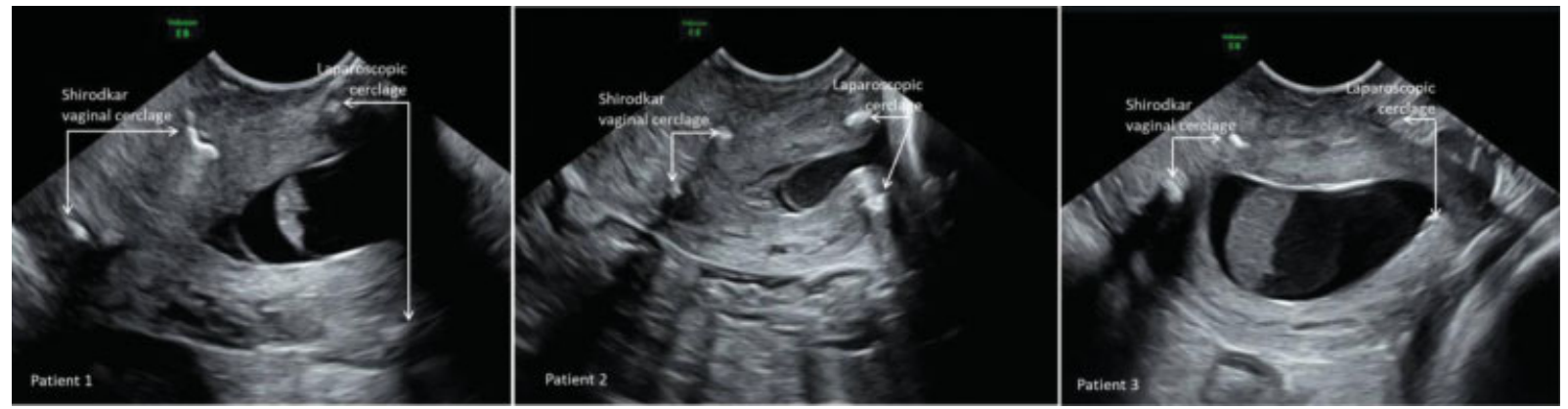

Fig. 1 Ultrasonography images of the patients' cervixes after Shirodkar vaginal cerclage.

laparoscopic cerclage. In these cases, we preferred to supplement the previous laparoscopic cerclage with a subsequent vaginal one through the Shirodkar technique, which is performed at a higher level of the cervix compared with the McDonald technique. This intervention refortified the cervix mechanically for further dilatation. We suggest that the alternative use of this well-known technique may be considered in such difficult cases to provide live births for patients with long history of pregnancy loss.

Conflicts of Interests

The author has no conflict of interests to declare.

\section{References}

1 Eleje GU, Eke AC, Ikechebelu JI, Ezebialu IU, Okam PC, Ilika CP. Cervical stitch (cerclage) in combination with other treatments for preventing spontaneous preterm birth in singleton pregnancies. Cochrane Database Syst Rev. 2020;9(09):CD012871. Doi: 10.1002/14651858.CD012871.pub2

2 Green-Armytage VB, Browne JC. Habitual abortion due to insufficiency of the internal cervical os; a preliminary report of seven cases treated by a modified Shirodkar technique. BMJ. 1957;2 (5037):128-131. Doi: 10.1136/bmj.2.5037.128

3 van Dongen PW, Nijhuis JG. Transabdominal cerclage. Eur J Obstet Gynecol Reprod Biol. 1991;41(02):97-104. Doi: 10.1016/00282243(91)90086-Z

4 Clark NV, Einarsson JI. Laparoscopic abdominal cerclage: a highly effective option for refractory cervical insufficiency. Fertil Steril. 2020;113(04):717-722. Doi: 10.1016/j.fertnstert.2020.02.007

5 Shennan A, Chandiramani M, Bennett P, et al. MAVRIC: a multicenter randomized controlled trial of transabdominal vs transvaginal cervical cerclage. Am J Obstet Gynecol. 2020;222(03):261. e1-261.e9. Doi: 10.1016/j.ajog.2019.09.040

\section{Comments by the President of the National Commission Specialized in High-Risk Pregnancy (Febrasgo)}

\author{
Rosiane Mattar ${ }^{1}(\mathbb{0}$ \\ ${ }^{1}$ Escola Paulista de Medicina, Universidade Federal de São Paulo, São \\ Paulo, SP, Brazil
}

Abdominal cerclage should be restricted to cases in which it is impossible to perform the procedure vaginally, as it leads to greater maternal morbidity: it determines a greater risk of bleeding, infection, rupture of the membranes, and cesarean section. I think that, if Shirodkar cerclage was possible after laparoscopic surgery, it should have been the first treatment option, which would reduce the risks and guarantee success. In addition, the fact that the funnel appeared after surgery
Address for correspondence Rosiane Mattar, MD, Rua Botucatu, 740, Vila Clementino, São Paulo, SP, 04023-062, Brazil (e-mail: rosiane.toco@epm.br).

shows that the tape was not properly tightened in the suture via the abdominal route, keeping the canal widened, as if the cerclage had not been performed. Thus, cerclage via the abdominal route should be very well indicated and very well performed when necessary.

Conflicts of Interests

The author has no conflict of interests to declare. 